\title{
STUDENT TEACHERS' OPINIONS ABOUT USING AUTHENTIC MATERIALS AND TASKS FOR ACQUIRING ESTONIAN CULTURAL HISTORY
}

\author{
Kristel Ruutmets, Evi Saluveer, \& Mari Niitra \\ Institute of Education, University of Tartu (Estonia)
}

\begin{abstract}
According to the Estonian National Curriculum for Basic Schools (2011), students should value their cultural heritage. Therefore, schools should do everything to develop students' cultural awareness and knowledge. Despite the importance of the topic the curriculum does not specify how and where it should be taught and does not say which material to use. One possibility to address the problem is to use authentic materials and tasks. The latter offer numerous ways to learn about one's cultural history, and help to create a bridge between the classroom and real life. Authentic materials are not specifically created for pedagogic purposes while authentic tasks require students to learn, practise and evaluate material the same way as they would do in real life. The focus of the use authentic materials has so far been mostly on foreign language teaching and learning. However, they have a huge potential in acquiring cultural knowledge as they offer both current and historical information. The aim of the study was to find out future primary school teachers' opinions about the authentic materials and tasks used during the course "The Child in Estonian Cultural History". 25 first-year students who attended the course participated in the study. The data was collected from the students' written reflection and analysed qualitatively. The results revealed that the students understood the relevance of authentic materials and tasks in acquiring and appreciating one's cultural history. They believed that authentic materials and tasks enrich the teaching and learning process, and help to make connections to their everyday life. It also became evident that the students needed better instructions of how to find appropriate authentic materials and exploit them effectively in their future teaching career.
\end{abstract}

Keywords: Authentic material, authentic task, cultural history, students' opinions.

\section{Introduction}

The Estonian National Curriculum for Basic Schools (2011) defines value competence as one of the general competencies, which among others emphasises the ability to value students' connections to the cultural heritage of their country and nation. The latter refers to the spiritual and material cultural property transferred from previous generations to the next (Kuutma, 2007). Despite the importance of the topic, the curriculum does not specify how and where it should be taught and does not say which material to use. Authentic material could complement the traditional study materials used to learn about cultural history. What is more, according to the Estonian Occupational Qualification Standards for teachers (level 7) (2020), the obligatory competencies of a teacher include the ability to choose study materials suitable for the learning objectives and the level of the study group. In-depth consideration of the choice and objectives of the study material in teacher training is also recommended in the Estonian Report of 2018 OECD Teaching and Learning International Survey (Taimalu et al., 2020). In order for the students to develop an understanding of how to choose and assess study material in their future teaching careers, it is important for them to exploit authentic materials and the tasks based on them during studies.

The widespread definitions of authentic materials still relied upon come from years ago and they are predominantly related to foreign language learning. For instance, authentic materials can be defined as materials "which have been produced for purposes other than to teach language" (Nunan 1995: 54) or as texts which are "created to fulfil some social purpose in the language community in which it was produced" (Little et al., 1988: 27, referred to in Guariento \& Morley, 2001). Nevertheless, the use of authentic materials should not be limited to (foreign) language learning. They could successfully be exploited in various other subjects, especially considering the definition of the word "authentic" as genuine, real, true-to-life. According to Mishan (2005: 46), authentic materials are like 'treasure chests of 
cultural exploration', providing up-to-date and historical information that can be used to raise learners' cultural awareness. Hereby it is important to find material that relates to the learners' cultural background and helps to understand its nuances (McGrath, 2016). In addition to traditional authentic materials (e.g. newspapers, books, films), the digitalisation of cultural heritage gives access to various materials, such as archival documents, databases and other publications. Exposure to authentic materials could also be linked to non-formal learning environments (e.g. museums, archives, libraries) and meaningful real-life tasks. The connection to real life in authentic tasks has been emphasized by many researchers (Mishan, 2017, Mueller, 2018, Oliver, Herrington, \& Reeves, 2002, Richards, 2006, Tomlinson, 2017). Such tasks are communicative in nature, and have a specific context and purpose (Mishan, 2017, Richards, 2006, Tomlinson 2017). Of equal importance is the accompanying learning process where new knowledge is acquired by independent research (Nicaise, Gibney, \& Crane, 2000). Tomalin and Stempleski (1993) stress that displaying a cultural document or artefact in class is not enough. Students need to be taught how to find appropriate information in the material.

Considering the importance of authentic material in bridging the gap between classroom and real life and their role in acquiring knowledge about one's cultural history, the study aimed at finding out future primary school teachers' opinions about the authentic materials and tasks used during the course "The Child in Estonian Cultural History". Based on the aim the following research questions were formulated:

1. Which positive aspects did the students point out in relation to the use of the authentic materials and tasks in learning Estonian cultural history?

2. Which problems did the students describe in relation to the use of the authentic materials and tasks?

3. How did the students assess the experience of using authentic materials and tasks in relation to their future teacher careers?

\section{Method}

\subsection{Sample}

The sample included 25 first-year students of the curriculum of primary school teacher at the University of Tartu (Estonia), who completed the compulsory course "The Child in Estonian Cultural History" in spring 2020. The study was conducted during the course and participation in it was voluntary. While presenting the results, the students' names are not mentioned to guarantee their anonymity.

\subsection{Data collection and procedure}

Qualitative research, which enables to address questions about the experience and perspectives of the participants, was employed in the study. During the course the students had to complete three tasks: 1) a short presentation about a toy after a visit to Tartu Toy Museum; 2) an analysis of an autobiographical children's book; 3) research work based on interviewing a family member about their childhood. The tasks were based on the use of different authentic materials and enabled the students to learn more about Estonian cultural history. After completing the tasks in May 2020 the students had to write a written reflection based on open questions related to the research questions of the study. The average length of the reflection was $1.5 \mathrm{~A} 4$ pages.

\subsection{Data analysis}

Thematic analysis was used to analyse the results obtained from the students' written reflections. The analysis was carried out in several phases, suggested by Brown and Clark (2006). First, every author read and re-read some of the students' reflections, independently identified meaningful units (words, phrases, sentences) and labelled them with initial codes. Then, to increase the trustworthiness of the study, all the authors together reviewed the initial coding in all the reflections and in the case of differences in coding reached a consensus. Next, similar codes were grouped into potential sub-themes, which in their turn were categorised under main themes. Finally, the sub-themes and main themes were reviewed and refined according to the research questions.

\section{Results}

\subsection{Positive aspects in relation to the use of the authentic materials and tasks in learning Estonian cultural history}

When analysing the data, the following sub-themes were identified: attractiveness of the materials and tasks, and benefits of the tasks in learning cultural history. 
Attractiveness of the materials and tasks. In the case of the presentation of a toy after a museum visit, the students appreciated the informal environment and free choice of the toy the most. The toys were considered exciting and innovative material, which in the students' opinion helped to make a personal connection with their parents' and grandparents' past. The students found the task fun and stressed a good alternative to traditional learning in the classroom. Another positive aspect of the task was its simplicity. A number of the students also mentioned that they enjoyed listening to the fellow-students' presentations. The second task, the book analysis, received the most variable evaluations. The students had to choose an autobiographical children's book from the given list. Not all the students considered the book they chose interesting. However, those who did pointed out that it enabled them to draw parallels with their own childhood. They also appreciated the connections between the theoretical materials used during the course and themes exposed in the chosen books. An alternative way of learning history instead of memorising historic dates was mentioned a number of times. The third task - research about one's family member's childhood - was considered the most favourite task by the majority of the students. Aspects such as an interesting and exciting process, new information about the family member's past and emotional connections to their relatives were repeatedly mentioned. Based on the students' reflections it could be concluded that all the used authentic materials and tasks increased the students' interest in historical objects, events and related literature and helped to make connections between the present and the past.

Benefits of the tasks in learning cultural history. Several benefits of the tasks were named. The visit to the toy museum made the students realise the rich possibilities of such learning process. Despite the simplicity of the task, it helped to exemplify different historical periods. When it comes to the reading task, increased awareness in using a literary work and its usefulness in understanding historic events was highlighted. The autobiographies the students read enabled them to see the 'big picture' of the Soviet period. The task also gave inspiration for similar tasks to be used in their future career. The third task about a family member's childhood helped the students to understand the past in a wider historical context, putting their family history in the centre of the events. Comparing their own childhood experiences with those of their relatives was considered to be a valuable experience. The task inspired some of them to study their family history more thoroughly in order to write it down for the future generations.

\subsection{Problems described in relation to the use of the authentic materials and tasks}

The data analysis revealed the following sub-themes: problems related to the materials and problems related to the tasks.

Problems related to the materials. One of the problems brought out in relation to the first two tasks was making an informed choice. The variety of different toys made it difficult to focus on one particular toy. Limited information about a chosen toy at the museum exposition was also mentioned. Some students were dissatisfied with the chosen book and found it difficult to understand or boring. They said it was due to particular style and old-fashioned vocabulary. The lack of documented personal archives in some cases also complicated doing research on a family member's childhood.

Problems related to the tasks. The students reported little previous experience in analysing literary texts. Hence, they were worried about the tendency to retell the story instead of analysing it. While researching a family member's past, mainly practical problems were indicated, e.g. lack of family photos from a particular period, difficulty visiting elderly relatives during the Corona pandemic in spring 2020 , organisation of the working process and finalising the results. The students repeatedly stressed the need for more concrete instructions for analysing books and conducting research. Some students would have preferred indicative questions about each book and a clear structure and format of the expected outcome.

\subsection{The experience of using authentic materials and tasks in relation to their future teacher careers}

Using authentic materials and doing authentic tasks during the course enriched the students' understanding of different learning environments and materials. Most of the students claimed that they would certainly use similar tasks with authentic materials in their future teaching. They saw the former as a possibility to diversify the learning process and make subjects more attractive. On the other hand, students could add very few original ideas of their own. Watching and analysing old TV commercials, interviewing classmates, using Google Maps street views were suggested by some students. 


\section{Discussion and conclusions}

Authentic materials and tasks are important for learning about cultural heritage, both material and spiritual. They create perspective, help put details in a broader context, and develop a deeper understanding of certain historical periods. The connections made during the study process with one's personal life and family history motivate students and help to make learning meaningful. The relevance and cultural appropriateness of authentic materials and tasks as well as students' intrinsic interest in them have been stressed by several authors (e.g., Belet Boyaci \& Güner 2018, McGrath, 2016). The authentic materials used in the course "Child in Estonian Cultural History" and the tasks based on them were highly evaluated by the students. They were seen interesting and meaningful bringing variety to the traditional classroom. The students realised the tasks' "enriching potential in the learning process" (Black 2005: 158). In addition, the respondents also appreciated the variety and novelty of the tasks, and alternative learning environments.

However, it became obvious that the students are used to detailed instructions and felt uncertain when given more freedom in completing tasks that require improvisation and varied outcomes. At the same time, it is important that in completing authentic tasks students should be encouraged to construct their own responses (Mueller, 2018) rather than using existing algorithms (Oliver et al., 2002). The respondents' uncertainty about their work may be due to the results-oriented school system in Estonia. At the same time, it became evident that real-life tasks helped the learners to create meaningful connections with the past and place personal experiences in a broader context. In this way, history, which for many was previously related to memorising facts, acquired a new meaning. According to Tomlinson (2013: 27), foreign language teaching "materials which address the learner in an informal, personal voice are more likely to facilitate learning than those which use a distant, formal voice." The present study confirms the idea that authentic materials can have a much wider role in teaching and their use should not only be limited to language learning. The tasks gave students the confidence to use authentic material and related tasks in their future teaching. Teachers' experience during their studies creates a context for their further choices (Falk et al., 2006). Therefore, their insecurity about doing authentic tasks may influence their future decisions on the choice of appropriate materials and tasks.

Based on the findings of the study, the following recommendations can be made. Authentic materials are an inexhaustible source in acquiring knowledge. When used together with meaningful authentic tasks, they give learners a deeper insight into a studied topic. On the other hand, the teacher's role in using authentic materials and tasks should not be underestimated. Students should be helped to choose appropriate material and be equipped with concrete selection criteria. Also, samples of the expected outcome can be demonstrated by the teacher to give students a better understanding of the task. It is also important to develop student-friendly guidelines for using authentic materials that are relevant to the content of a particular subject. Such materials would offer future teachers useful ideas and techniques and encourage them to put these ideas into practice. As a result, more teachers would be motivated to use 'the real' (McGrath, 2016) in their lessons and courses.

\section{References}

Belet Boyacı, Ş. D., \& Güner, M. (2018). The impact of authentic material use on development of the reading comprehension, writing skills and motivation in language course. International Journal of Instruction, 11(2), 351-368. doi.org/10.12973/iji.2018.11224a

Black, G. (2005). The Engaging Museum: Developing Museums for Visitor Involvement. London \& New York: Routledge.

Brown, V., \& Clarke, V. (2006). Using Thematic Analysis in Psychology. Qualitative Research in Psychology, 3, 77-101.

Falk, J. H., Dierking, L. D., \& Adams, M. (2006). Toward a Usable Model for Understanding Learning in Museums. In S. MacDonald (Ed.), A Companion to Museum Studies (pp. 323-329). London, Blackwell Publishing.

Guariento, W., \& Morley, J. (2001). Text and task authenticity in the EFL classroom. ELT Journal, 55 (4), 347-353. doi.org/10.1093/elt/55.4.347

Kuutma, K. (2007). Kultuuripärand. In T. Jaago (Ed.), Argikultuuri uurimise terminoloogia e-sõnastik. Retrieved April 13, 2021, from https://argikultuur.folklore.ee

McGrath, I. (2016). Materials Evaluation and Design for Language Teaching (2 ${ }^{\text {nd }}$ edition). Edinburgh: Edinburgh University Press Ltd.

Mishan, F. (2005). Designing Authenticity into Language Learning Materials. Bristol: Intellect Books. 
Mishan, F. (2017). 'Authenticity 2.0': Reconceptualising 'Authenticity' in the Digital Era. In A. Maley \& B. Tomlinson (Eds.), Authenticity in Materials Development for Language Learning (pp. 10-25). Newcastle upon Tyne: Cambridge Scholars Publishing.

Mueller, J. (2018). Authentic tasks. Retrieved March 25, 2021, from http://jfmueller.faculty.noctrl.edu/toolbox/tasks.htm

National Curriculum for Basic Schools (2011). Riigi Teataja I, 14.01.2011. Retrieved April 29, 2021, from https://www.riigiteataja.ee/en/eli/524092014014/consolide

Nicaise, M., Gibney, T., \& Crane, M. (2000). Toward an Understanding of Authentic Learning: Student Perceptions of an Authentic Classroom. Journal of Science Education and Technology, 9(1), 79-94.

Nunan, D. (1995). Designing Tasks for the Communicative Classroom. Cambridge: Cambridge University Press.

Occupational Qualification Standards: Teacher, EstQF Level 7 (2020). Retrieved January 22, 2021, from https://www.kutseregister.ee/ctrl/et/Standardid/vaata/10824233

Oliver, R., Herrington, J., \& Reeves, T. (2002). Authentic activities and online learning. Retrieved March 27, 2020 from https://ro.ecu.edu.au/ecuworks/3900

Richards, J. C. (2006). Communicative Language Teaching Today. Cambridge: Cambridge University Press.

Taimalu, M., Uibu, K., Luik, P., Leijen, Ä., \& Pedaste, M. (2020). Õpetajad ja koolijuhid väärtustatud professionaalidena. OECD rahvusvahelise õpetamise ja opppimise uuringu TALIS 2018 uuringu tulemused (2). Tallinn: SA Innove. Retrieved from https://www.innove.ee/wpcontent/uploads/2020/04/TALIS2_kujundatud.pdf

Tomalin, B., \& Stempleski, S. (1993). Cultural Awareness. Oxford: Oxford University Press.

Tomlinson, B. (2013). Materials Evaluation. In B. Tomlinson (Ed.), Developing Materials for Language Teaching (2 ${ }^{\text {nd }}$ edition) (pp. 21-48). London, New Delhi, etc.: Bloomsbury Academic.

Tomlinson, B. (2017). Introduction. In A. Maley \& B. Tomlinson (Eds.), Authenticity in Materials Development for Language Learning (pp. 1-9). Newcastle upon Tyne: Cambridge Scholars Publishing. 